\title{
Why Are Crisis-Induced Devaluations Contractionary? Exploring Alternative Hypotheses
}

\author{
Ramkishen S. Rajan \\ George Mason University \\ Chung-Hua Shen \\ National Chengchi University
}

\begin{abstract}
Why are some currency crises followed by economic contractions while others are not? This paper is an attempt at answering this query. In particular, we investigate two closely related questions. First, we explore whether there is a difference in the output effects of a devaluation during "normal" periods versus crises ones; after all, during non-crisis periods, real exchange devaluation is seen as an important policy option for promoting exports and output growth. Yet, the literature has not made a distinction between crisis and non-crisis periods. To preview the main conclusion, we find that the contractionary effects tend to exist only during the crisis period. Building on this, we go on to explore the factors that cause a crisis-induced devaluation to be contractionary.
\end{abstract}

- JEL classification: F34, F41, F42

- Keywords: Capital flows, Currency crisis, Contractionary devaluation, Speculative attack

\footnotetext{
*Corresponding address: Ramkishen S. Rajan, School of Public Policy, George Mason University MSN 3B1 3401 N. Fairfax Drive Arlington. VA 22201 USA. E-mail: rrajan1@gmu.edu.tw.

Chung-Hua Shen, Department of Money and Banking, National Chengchi University Taipei, Taiwan. Email: chshen@ nccu.edu.tw

(C2006-Center for International Economics, Sejong Institution, All Rights Reserved.
} 


\section{Introduction}

The Mexican crisis of 1994-95 followed by the East Asian crisis of 1997-98 and the other crises in Brazil, Russia and Turkey in 1999-2000 have generated a great deal of academic and policy interest on the causes of currency crises in emerging and developing economies. The main focus of this literature has been on whether the crisis was "inevitable" (first generation models) or "self-fulfilling" (second generation models). A common element in both these two genre of crisis models is that if a speculative attack is successful in breaking down the currency peg, the resulting devaluation ought to mark the end of the crisis. Real devaluation, according to the conventional view, would have expansionary effects because it increased the demand for tradables (Dornbusch, 1988). In practice, the postdevaluation experiences have varied markedly among countries. Some countries like Brazil seemed to recover smartly following the initial devaluation of the real. Others underwent a considerable output contraction immediately following floatation of the respective currencies. Kamin and Rogers (2000) and Santaella and Vela (1996) confirm this (contraction) to have been the case for Mexico following the 1994-95 crisis and Moreno (1999) shows it to have held for East Asia in general ${ }^{1}$.

In view of the above, Dooley and Walsh (2000) have commented, "(w)e are unsure why some crises are followed by long periods of economic recession while others are not" (p.3). This paper is an attempt at answering this query. In particular, we investigate two closely related issues. We first explore whether there is a difference in the output effects of a devaluation during "normal" periods versus crisis ones; after all, during non-crisis periods, real exchange devaluation is seen as an important policy option for promoting exports and output growth ${ }^{2}$. Yet, the literature has not made a distinction between crisis and non-crisis periods. To preview the main conclusion, we find that the contractionary effects tend to exist only during the crisis period. Building on this, we go one to explore the factors that cause a crisis-induced devaluation to be contractionary.

The remainder of this paper is organized as follows. Drawing upon recent analytical

\footnotetext{
${ }^{1}$ See Bird and Rajan (2004) for a case-study of Thailand, the trigger country in the East Asian crisis of 1997-98.

${ }^{2}$ For instance, Rodrik (2000) has noted: there is every reason to think that..(the)..real depreciations were an important boost to economic activity, particularly in tradables, and not simply something that went alongside higher growth. They unleashed energies and focused them on world markets, boosted exports, and set the stage for economic transformation (pp.8-9).
} 
literature on currency crises and capital flows, the next section synthesizes the reasons for and channels via which a devaluation is contractionary. This section outlines the specific hypotheses to be tested. Section 3 and 4 respectively describe the econometric model and the data to be used in the analysis. The main results are summarized in section 5 . The final section offers a summary and a few concluding remarks.

\section{Devaluation in Emerging and Developing Economies: Contractionary Channels}

\section{A. New Structuralist School: Current Account Channels}

There exists a rich early literature that has detailed the various channels by which a devaluation might be contractionary in emerging and developing economies due to their unique economic structures, a point stressed by the socalled "New Structuralist" school (Taylor, 1981). There are various well established routes via which devaluation may, in principle, have a contractionary effect that spans both aggregate demand and aggregate supply (see the well-cited papers by Edwards, 1989, Lizondo and Montiel, 1989, and van Wijnbergen, 1986 for comprehensive reviews; Cooper, 1971 provides one of the earliest systematic surveys).

On the demand side, and with both a high average propensity to import and a low price elasticity of demand for imports, devaluation will tend to divert domestic monetary demand away from home produced goods. The income redistributive effects of devaluation will favor profits in the traded goods sector - the mechanism through which devaluation affects the current account - and disfavor real wages, as the price level rises. However, spending and savings propensities may differ as between those receiving profits and wages. If the marginal propensity to save is higher from profits than from wages the economy's average propensity to save will rise and this will tend to lead to a contraction in aggregate demand. (Diaz-Alejandro, 1963, Knight 1976). On the supply side, there are again a number of channels through which devaluation may exert a recessionary impact. To name one, the domestic currency costs of imported inputs will rise, leading to stagflationary effects.

Regardless of the exact channels, this New Structuralist School opines that devaluation is more likely the lower the income level of the country. Thus, Hypothesis 1 is as follows: The lower the per capita income level of a country the more likely that 
devaluation is contractionary. We refer to this as the "Income effect"3.

\section{B. Regional Contagion Effects}

An important characteristic of emerging and developing economies is that a currency crisis tends to be accompanied by contagion or negative spillover effects that are largely regional in scope (consequently, they are also referred to as "neighborhood effects"). For instance, while the East Asian crisis did threaten to turn global, it did not. Similarly, while the currencies of Thailand, Hong Kong and the Philippines underwent brief periods of speculative attacks during the Tequila crisis, the crisis predominantly affected Mexico's neighboring economies (such as Argentina). In a study using a sample of 20 countries covering the periods of the 1982 Mexican debt crisis, the 1994-95 Tequila crisis and the 1997-98 Asian crisis, De Gregario and Valdes (2001) found contagion to be directly dependent on geographical horizon. Using a panel of annual data for 19 developing economies for the period 1977-93, Krueger et al (2000) concluded that a currency crisis in a regional economy raises the probability of a speculative attack on the domestic currency by about 8.5 percent points ${ }^{4}$. Thus, even if the New Structuralist arguments are rejected, it is possible that devaluation may fail to boost exports if regional contagion effects accompany it. In other words, currency devaluation in one economy may provoke a devaluation in one or more trade competitors (i.e. other economies with similar export structures/comparative advantage) that suddenly finds itself at a competitive disadvantage.

Gerlach and Smets (1995) is a pioneering attempt at modeling the phenomenon of competitive devaluation. Their trade spillover model consists of two channels via which a trade partner is impacted. In the primary channel, devaluation in an export competitor leads to a deterioration in the trade balance in the partner country, causing a speculative attack on the latter. In the secondary channel, devaluation lowers the aggregate price level and demand. This leads to the domestic currency being substituted for foreign currency, depleting international reserves and making

\footnotetext{
${ }^{3}$ Regression analysis of twelve developing economies for the period 1965-80 by Edwards (1986) suggested that real devaluations have a small contractionary effect in the short run but are neutral in the long run. However, in a broad survey of the empirical evidence, Kamin (1988) concluded that there was no empirical evidence to support the claim that devaluation per se was contractionary. He found that, more often that not, recessions preceded devaluation. Also see Kamin and Klau (1998).

${ }^{4}$ Other recent empirical studies confirming this regional dimension of currency crises include Calvo and Reinhart (1996), Frankel and Schmukler (1996), Glick and Rose (1999) and Kaminsky and Reinhart (2000).
} 
the economy vulnerable to a classic speculative attack. Two other recent models of competitive devaluation are by Huh and Kasa (1997) and Corsetti, Pesenti and Roubini (2000) which is built on microfoundations. The Corsetti-Pesenti-Roubini model shows how a game of competitive devaluation could generate currency overshooting if market participants, anticipating that a series of competitive devaluations will occur once there is a successful speculative attack in one country, flee altogether from the trade competitors ${ }^{5}$.

This leads to Hypothesis 2: Devaluation may be contractionary in the presence of regional "contagion". We dub this the "Regional effect".

\section{C. "Twin" Crisis}

An important channel ignored by the older literature is the so-called "balancesheet effect" due to sizeable unhedged exposures to short term foreign currency denominated debt (Aghion et al., 2000 and Krugman, 1999a,b) ${ }^{6}$. The rise in corporate bankruptcies due to an escalation in domestic currency liabilities inevitably leads to large-scale domestic "credit rationing", as decapitalized banks, burdened by large non-performing loans (NPLs), curtail their lending ${ }^{7}$. It is therefore not surprising that currency crises in emerging and developing economies often tend to be accompanied by banking crises. The co-existence of banking and currency crises has been found to be the norm during the late 1980s and early 1990s (Kaminsky

\footnotetext{
${ }^{5}$ The Corsetti-Pesenti-Roubini model also consists of a "bilateral trade" or "cheap imports" effect which is welfare enhancing, as it allows the importing country to enjoy a higher level of consumption. As they show, if this effect dominates the welfare-reducing one due to loss of product competitiveness, devaluation in one country may not necessarily lead to a net welfare loss to its trading partner. In other words, devaluation may not necessarily be "beggar-thy-neighbor".

${ }^{6}$ Over 50 percent of long term external debt in developing economies (for which data are available) is held in US dollars, with the remainder being held primarily in euros and Japanese yen. This inability by developing economies to borrow externally in their local currency has come to be referred to as the "original sin" hypothesis, a term attributed to Hausmann (1999). For a discussion of the implications of this original sin hypothesis on exchange rate policy in Southeast Asia, see Rajan (2002) and references cited within.

${ }^{7}$ We do not enter here into the controversial debate of defining what is meant by a "credit crunch" and how it is most appropriately measured, only recognizing that credit growth reflects both the demand for and supply of credit (see Lane and Associates, 1999, Lindgren et al., 1999 and Furman and Stiglitz, 1998).

${ }^{8}$ These "twin crises" have inspired a number of recent theoretical contributions to the literature on financial crises in emerging and developing economies. The pioneering work in this area is Velasco (1987), who introduced a banking sector within a conventional Krugman (1979) framework. Also see Shen (1999).
} 
and Reinhart, 1999), and these twin crises seem to be far more pervasive in developing economies than developed ones (Glick and Hutchison, 1999) ${ }^{8}$.

This leads to Hypothesis 3: Other things equal, devaluation accompanied by a banking crisis is more likely to be contractionary. We refer to this as the "Banking Crisis effect".

\section{Short Term Indebtedness}

Krugman (1999b) has noted that the positive pro-competitive effects of a devaluation would dominate for "small" variations in the exchange rate, resulting in a devaluation being expansionary; while the negative balance sheets effects may dominate for "large" devaluations, resulting in an income contraction. The conundrum is that even a small devaluation in emerging and developing economies may act as a trigger leading to sharp capital outflows and an outright economic collapse after the initial devaluation. Thus, Krugman (1998) has noted,

nobody who looks at the terrible experiences of Mexico in 1995 or Thailand in 1997 can remain a cheerful advocate of exchange rate flexibility. It seems that there is a double standard on these things: when a Western country lets its currency drop, the market in effect says "Good, that's over" and money flows in. But when a Mexico or Thailand does the same, the market in effect says "Oh my God, they have no credibility" and launches a massive speculative attack. So the question for..(emerging and developing economies)..is, do you think that the market will treat you like Britain, or do you think it will treat you like Mexico? And this is not an experiment that any responsible policymaker wants to try9.

In other words, if devaluation damages confidence it may result in additional capital outflows. This in turn could cause a further decline in the currency's value that was anticipated, leading to a vicious spiral of crisis-induced devaluation, illiquidity and insolvency of financial institutions and corporates, and eventual outright economic collapse.

Received wisdom linking the composition of international capital flows to economic

${ }^{9}$ Calvo (1996) makes a similar point. It is actually interesting to recall the debate prior to the Mexican crisis documented in the Brookings Economic Papers in 1994. While Rudiger Dornbusch and Andrew Werner had proposed a devaluation of the peso of about 20 percent prior to the Mexican crisis, Guillermo Calvo (1994) was on record as opposing the peso devaluation, arguing that "( $t$ )his is not the time to implement a Dornbusch-Werner devaluation. The forces that have held together the 'good' equilibrium...may dissipate overnight" (p.303). 
instability and financial crises is quite straightforward. Short term inflows (or "hot money"), it is argued, can be easily reversed. Thus, Fernández-Arias and Hausmann $(2000,2001)$ refer to short term debt as "bad cholesterol" as it is motivated by "speculative considerations" such as interest rate differentials and exchange rate expectations ${ }^{10}$. This type of financing is the first to exit in times of trouble, the resulting boom-bust cycle of capital flows in the 1990s having inflicted great damage to small and open economies. The extent of short term indebtedness has been found to be a robust predictor of financial crises (Dadush et al., 2000, Rodrik and Velasco, 1999 and World Bank, 2000). According to Dadush et al., on the basis of data for 33 developing economies, the elasticity of short term debt with GDP growth is 0.9 when there is a positive shock to output and -1.8 when there is a negative shock. This extreme reversibility of short term debt in the event of negative shock exposes borrowers to liquidity runs and systemic crises.

This implies a further hypothesis to be tested. Hypothesis 4: The larger the level of short term indebtedness, ceteris paribus, the greater the likelihood that devaluation will be contractionary. We refer to this as the "Excessive Debt effect".

\section{E. Composition of Capital Flows and Corruption}

The preceding emphasis on short term debt leaves the analysis open to two criticisms.

One, short term debt is by no means the only form of liquid liability. An alternative more complete - measure of illiquidity is given by "mobile capital" or international capital markets, which refers to short term bank loans plus portfolio investment in the form of equity and bond issues in offshore markets. Unfortunately, significant data problems exist in the case of components of international capital flows. These take the form of data unavailability as well as concerns regarding possible substitutability between various types of capital flows (see Fernández-Arias and Hausmann, 2000, 2001 and Rajan and Siregar, 2002).

Two, there is an active parallel area of research that has identified insolvency caused by poor public governance or "crony capitalism" as an important reason for crises in emerging and developing economies, especially in East Asia in 1997-98. Wei (2001) and Wei and $\mathrm{Wu}(2001)$ provide a way of resolving the illiquidity versus crony capitalism debate. Countries that are corrupt, and are therefore vulnerable to insolvency, tend also to have capital inflows that are biased away from more "secure" forms of financing (like FDI) towards the highly mobile variety, hence making

\footnotetext{
${ }^{10}$ Prominent examples of illiquidity models include Chang and Velasco (1999) and Goldfajn and Valdes (1997), which are essentially open economy extensions of the Diamond and Dybvig (1983) bank panic model.
} 
them susceptible to illiquidity crises.

This leads us to Hypothesis 5: The higher the level of corruption, ceteris paribus, the greater the likelihood that devaluation will be contractionary. We refer to this as the "Corruption effect".

\section{F. State-Contingent Devaluation}

An important but oft-ignored analytical point is that the New Structuralist hypothesis (Hypothesis 1) opines that devaluations in emerging and developing economies will be contractionary regardless of whether it occurs during a period of "crisis" or a relatively tranquil (i.e. non-crisis) one. In contrast, the other hypotheses noted here are more specifically relevant to the currency crisis periods. Therefore, before going on to test the five hypotheses set out above, we first investigate whether the output effects of devaluations in economies vary between crisis and non-crisis periods, i.e. "state contingent devaluation".

\section{Model Design and Sample Countries}

\section{A. Econometric Model}

On the basis of the discussion in the previous section, we take a two-step approach in our econometric model. We first explore whether output does contract after a currency crisis. We then investigate the reasons for contraction based on the five hypothesis outlined in the previous section. The two step method is as follows:

$$
\begin{aligned}
y_{i t}-\tilde{y}_{i t}= & \left(\alpha_{0}^{(1)}+\alpha_{1}^{(1)}\left(e_{i t}-\tilde{e}_{i t}\right)\right) I_{i t}+\left(\alpha_{0}^{(2)}+\alpha_{1}^{(2)}\left(e_{i t}-\tilde{e}_{i t}\right)\right)\left(1-I_{t}\right) \\
& +\beta\left(X_{i t}-\tilde{X}_{i t}\right)+\varepsilon_{t} \quad i=1, \ldots, N, \quad t=1, \ldots, T
\end{aligned}
$$

where $I_{i t}$ is the indicator function and

$$
\begin{aligned}
I_{i t} & =1 \text { if there is no crisis } \\
& =0 \text { if there is a crisis }
\end{aligned}
$$

$y_{t}$ is the real output, $e$ is the real exchange rate, $X$ is the vector of controlled

\footnotetext{
${ }^{11}$ Hutchison (2001), in a study of IMF-supported stabilization programs, considers a somewhat different specification. The variables he includes in his specification are the inflation, credit growth and real GDP growth, external growth rate and the real exchange rate overvaluation at $t-1$.
} 
variables, including government expenditure $(g)$, domestic interest rate $(r)$ and monetary policy $(m)$. This is based on Agenor (1991) and Moreno (1999) ${ }^{11}$. The tilde $(\sim)$ denotes the expected trend, $i$ refers to the country and $t$ is the time period. All $y_{\mathrm{it}}$ variables are adjusted using deviation from the expected trend. $z$ denotes our hypothesized variables, i.e. proxies for GNP per capita (income), regional effect (region), banking crisis $(b c)$, excessive short term debt hypothesis (debt), and poor public governance (proxied by corrupt), which represent the five hypotheses mentioned in the previous section. The coefficients $\alpha_{0}^{(k)}, \alpha_{1}^{(k)}, \theta_{0}^{(k)}$ and $\theta_{1}^{(k)}$ are unknown parameters, where $k=(1,2)$ denotes the crisis regimes.

The intuition guiding our econometric model is straightforward. The first step measures the responses of output to exchange rate movements in the "normal time" (noncrisis period) and the responses during the crisis period, respectively, separated by indicator $I$. That is, the output effects of exchange rate variations are different across the two regimes (i.e. crisis versus non-crisis).

$$
\begin{aligned}
\partial y_{t} / \partial e_{t} & =\alpha_{1}^{(1)}=0 \text { if there is no crisis, or no "successful attack" } \\
& =\alpha_{1}^{(2)}<0 \text { if there is a crisis, or a "successful attack" }{ }^{\prime 2}
\end{aligned}
$$

In this step, the exchange rate response of output is constant within each regime but differs across regimes. We expect significant negative responses of output to exchange rate variations during the currency crisis, and no response or even a positive one in the absence of a crisis (we define what we mean by "currency crisis" in the next section). This specification differentiates our paper from past studies which do not distinguish the output responses during normal times and chaotic ones. Failure to make this distinction could lead to misleading results and conclusions.

The second step concerns the reasons causing the output collapse. We relate the response coefficient $\alpha_{i}^{(k)}$ to a constant $\theta_{0}^{(k)}$ and $z_{t}$. That is, the response coefficients are:

$$
\begin{aligned}
& \alpha_{1}^{(1)}=\theta_{0}^{(1)}+z_{t} \text { if there is no crisis, or no successful attack } \\
& \alpha_{1}^{(2)}=\theta_{0}^{(2)}+\theta_{1}^{(2)} z_{t} \text { if there is a crisis, or a successful attack }
\end{aligned}
$$

where $z_{t}$ is the proxy of above-mentioned five hypotheses alternatively, viz.,

\footnotetext{
${ }^{12} \mathrm{We}$ define these states of nature more precisely in the next section.
} 
$z_{t}=\{$ income, region, banking crisis, debt, corrupt $\}$

The Income effect hypothesis is proxied by GNP per capita. Based on the New Structuralist arguments we expect the coefficient to be positive, i.e. the lower the income level the more likely it is that devaluation is contractionary.

The Regional effect is proxied by regional dummies for Latin America, Asia, Nordics, Southern Europe and others (sample used is described in the next section).

The third hypothesis pertains to the "twin crisis", i.e. coincidence of currency and banking crises. This banking crisis hypothesis is proxied by a variable containing dates of banking crisis of each country. This dummy variable is denoted as $b c$, which is equal to one if there is a banking crisis simultaneously with a currency crisis, otherwise it takes on a zero value.

The Excessive debt hypothesis is proxied by short term debt as a proportion of total external debt. Unfortunately, such data are only available for developing countries in the World Bank's databank. As such, the Nordic countries are excluded when this hypothesis is tested. The coefficient is expected to be negative for reasons already outlined.

The Corruption hypothesis is proxied by a dummy variable ranging from 0 to 10. This dummy is taken from LaPorta, Lopez-de-Silanes, Shleifer and Vishny (hereafter LLSV) (1998). The index is based on the International Country Risk's assessment of government corruption levels across countries. A lower scores indicates that "high government officials are likely to demand special payments" and "illegal payments are generally expected throughout lower levels of government". Thus, a higher score indicates less corruption and vice versa.

\section{Data and Descriptive Statistics}

\section{A. Sample Countries}

We consider 25 countries in this study. There are nine Latin American countries, including Argentina, Bolivia, Brazil, Chile, Columbus, Mexico, Peru, Uruguay, Venezuela; five Asian countries, including Indonesia, Malaysia, Philippines, South Korea and Thailand; four Nordic countries, including Denmark, Finland Norway and Sweden; three South European countries, including Czech Republic, Greece, Spain; and others including Egypt, Israel, South Africa and Turkey. These 25 countries are selected based on the monograph by Goldstein, Kaminsky and Reinhart (2000) which provides dates of currency and banking crises of the above 25 sample countries. 
Goldstein et al. (2000) define the date of currency crisis as a situation in which an attack on the currency leads to a "substantial reserve loss" or to a "sharp depreciation of the currency". Insofar as our five hypotheses ought, strictly speaking, to pertain only to a successful speculative, i.e. actual devaluation, we consider both the cases of a currency crisis as defined above as well as the case of only a "successful attack", i.e. actual devaluation. We date an attack as "successful" if the percentage change of the exchange rate exceeds 1.65 times one standard deviation of the percentage change of the exchange rate. While many researchers also use 1.65 times one standard deviation of the percentage change of exchange rate as the criteria for defining a crisis, such a technical rule is not without its flaws. Nonetheless, different mechanical criteria, such as using 1.96, do not alter the results significantly.

The date of a banking crisis is characterized by two types of events: bank runs that lead to the closure, merger, or takeover by the public sector of one or more financial institutions; and if there are no bank runs, the closure, merging, takeover, or large-scale government assistance of an important financial institution. Admittedly, there may be a selection bias since floating exchange countries and developed countries are excluded. As such, countries like the United Kingdom which suffered from a currency crisis during the September 1992 are not listed in Goldstein et al. (2000).

The sample initially spans the period 1981 to 1999; annual data is used. All data are taken from International Financial Statistics published by the International Monetary Fund and the World Development Indicator published by World Bank. Though the Czech Republic is included in the plot in Figure 1, it is excluded from our econometric model since the data are only available from 1993.

Following Moreno (1999) we consider two expected trends to remove non-stationary of variables. We first use the polynomial trended method. The expected trend method is obtained by regressing the variables on a constant, linear, quadratic, cube and quadruplet trends to obtain filtered variables. We then consider the HodrickPrescott trend method. The two filters yield broadly similar results.

\section{B. Descriptive Statistics}

Table 1 reports the average growth rate of GDP and the five hypothetical proxies over the sample period for the countries under consideration. Since the numbers in Table 1 are averages over 25 years, their information may be limited due to the wide variations over these years. The first column is the average growth rate across 
Figure 1. Real GDP Classified by Region Latin America, Nordics, Middle East, Southern Europe and Asia
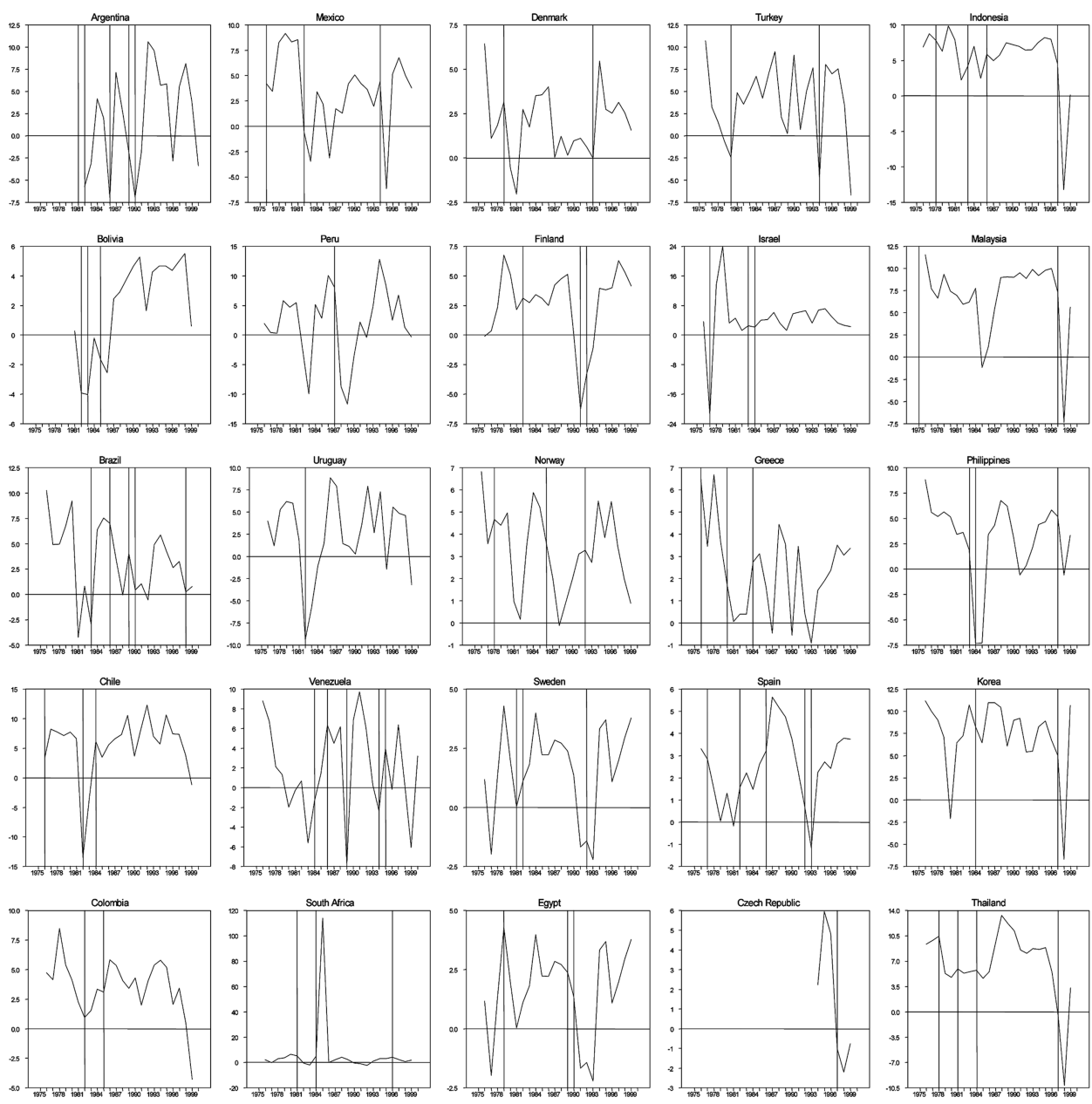

countries. Note that the Asian countries experienced a higher rate of growth than other countries in our sample despite the severe output contractions in 1997-98 by virtue of the phenomenal pre-crisis expansions. The next two columns are the currency and banking crises. The GNP per capita values are shown in the next column. The highest short term debt ratio is South Africa (43.68), followed by South Korea (30.73). The final column shows the corruption index.

Figure 1 plots the 25 countries as well as their respective currency crises. It is worth noting that while the plots are based on the growth rate, the actual estimation is based on the deviation from expected trend. Figure 2 is the output growth pre 
Table 1. Country Information: Average GDP Growth and Proxies for the Five Hypotheses

\begin{tabular}{|c|c|c|c|c|c|}
\hline Countries & $\begin{array}{l}\text { GDP } \\
\text { Growth } \\
(\%)\end{array}$ & $\begin{array}{c}\text { Currency Crisis } \\
\text { (Dates) }\end{array}$ & $\begin{array}{c}\text { Banking-cum- } \\
\text { Currency Crises } \\
\text { (Dates) }\end{array}$ & $\begin{array}{c}\text { Short term } \\
\text { Debt/Total } \\
(\%)\end{array}$ & $\begin{array}{l}\text { Corruption } \\
\text { Index }\end{array}$ \\
\hline Argentina & 1.543 & $\begin{array}{c}1981,1982,1986 \\
1989,1990\end{array}$ & 1981,1986 & 20.15 & 6.02 \\
\hline Bolivia & 1.912 & $1982,1983,1985$ & & 10.91 & 6.00 \\
\hline Brazil & 3.252 & $\begin{array}{c}1983,1986,1989 \\
1990,1998\end{array}$ & 1986 & 15.33 & 6.32 \\
\hline Chile & 5.080 & $1976,1982,1984$ & 1982 & 16.98 & 5.30 \\
\hline Colombia & 3.458 & 1982,1985 & 1983,1985 & 21.51 & 5.00 \\
\hline Denmark & 1.943 & 1979,1993 & & NA & 10.00 \\
\hline Egypt & 1.593 & $1979,1989,1990$ & & 16.19 & 5.00 \\
\hline Finland & 2.524 & 1982,1991, 1992 & 1991,1992 & NA & 10.00 \\
\hline Greece & 2.282 & $1976,1980,1984$ & & NA & 7.27 \\
\hline Indonesia & 5.170 & $\begin{array}{c}1978,1983,1986 \\
1997\end{array}$ & & 15.43 & 2.27 \\
\hline Israel & 3.874 & $1977,1983,1984$ & 1983 & NA & 8.33 \\
\hline Malaysia & 6.576 & 1975,1997 & 1997 & 17.03 & 7.38 \\
\hline Mexico & 3.271 & $1976,1982,1994$ & 1982,1994 & 16.95 & 4.77 \\
\hline Norway & 3.215 & 1978,1986, 1992 & 1986 & NA & 10.00 \\
\hline Peru & 1.731 & 1987 & & 21.09 & 4.70 \\
\hline Philippines & 2.928 & 1983,1984, 1997 & 1983,1997 & 25.00 & 2.92 \\
\hline South Africa & 5.039 & 1981,1984, 1996 & & 43.68 & 8.92 \\
\hline Korea & 6.956 & 1984,1997 & & 30.73 & 5.30 \\
\hline Spain & 2.430 & $\begin{array}{c}1977,1982,1986 \\
1992,1993\end{array}$ & 1977 & NA & 7.38 \\
\hline Sweden & 1.593 & $1981,1982,1992$ & 1992 & NA & 10.00 \\
\hline Thailand & 6.344 & $\begin{array}{c}1978,1981,1984 \\
1997\end{array}$ & 1978,1992 & 29.86 & 5.18 \\
\hline Turkey & 3.698 & 1980,1994 & 1994 & 21.57 & 5.18 \\
\hline Uruguay & 2.419 & 1982 & 1982 & 20.75 & 4.00 \\
\hline Venezuela & 1.840 & $\begin{array}{c}1984,1986,1989 \\
1994,1995\end{array}$ & 1994 & 23.35 & 4.70 \\
\hline
\end{tabular}

Dates of currency and banking crises are taken from Goldstein, et al. (2000); Corruption Index is taken from LLSV(1998).

and post-crisis. Note that the average output for these 25 countries dropped when the crisis occurred. The average output continued to contract in the cases of the Latin American and Asian countries, but not for the other three regions.

\section{Estimation Results}


Figure 2. Output During Currency Crisis by Region


\section{A. Contractionary Devaluation Hypothesis}

Figure 3 shows the scatter plot of filtered log exchange rate and filtered log outputs. While the filter is based on the polynomial trended method, as noted, the results do not vary by much if the Hodrik-Prescott filter is used. Therefore, only the former filtered results are reported here. The plot is slightly negatively sloped with large variations, and is suggestive (but certainly not conclusive) of the contractionary devaluation hypothesis.

We estimate equation 1 for each country (excluding Czech Republic) and collect the estimated response coefficient of $\alpha_{1}$. Thus, we have 24 response coefficients and histograms of them and their associated $t$ values are plotted in Figure 4.18 out of 24 coefficients are negative and ten out of the 18 negative coefficients are significant at the 10 percent level. Hence, while negative coefficients are typically observed, seeming to support the contractionary hypothesis, the trend is blurred by 
Figure 3. Scatter Plot of Output and Exchange Rate

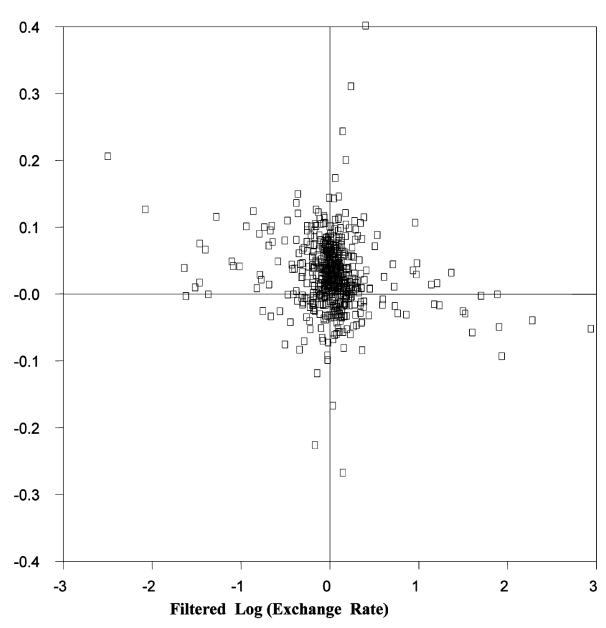

Figure 4. Histogram of Coefficients on Exchange Rates 24 Countires, Unbalanced Data, Max. Period = 1975-2000


the large variations.

Table 2 reports the estimation results of pooling 24 countries. Three distinct models are estimated -- a single regime or linear model (i.e. encompassing the entire sample period), and a pair of two-regime models. The first two-regime model is based on the currency crisis index (i.e. both successful and unsuccessful speculative attacks) and the second two-regime model is based on only the cases of 
Table 2. Contractionary Depreciation During Currency Crisis

\begin{tabular}{cccc}
\hline & $\begin{array}{c}\text { Linear/Single Regime } \\
\text { Model }\end{array}$ & $\begin{array}{c}\text { Two-Regime Model 1 } \\
\text { (Currency Crisis) }\end{array}$ & $\begin{array}{c}\text { Two-Regime Model 2 } \\
\text { (Successful Attack) }\end{array}$ \\
\hline \multirow{2}{*}{ Constant $\times I$} & -0.0033 & -0.0070 & 0.0070 \\
$(e-\tilde{e}) \times I$ & $(0.945)$ & $(0.935)$ & $(0.959)$ \\
& -0.0493 & 0.0008 & 0.0011 \\
Constant $\times(1-I)$ & $(1.013)$ & $(0.325)$ & $(0.458)$ \\
$(e-\tilde{e}) \times(1-I)$ & & -0.0243 & $-0.0034^{* *}$ \\
$g-\tilde{g}$ & & $(1.403)$ & $(2.196)$ \\
& & $-0.0474^{*}$ & $-0.0521^{*}$ \\
$m-\tilde{m}$ & $(0.889)$ & $(4.799)$ & $(4.986)$ \\
& $0.1204^{* * *}$ & 0.0131 & 0.0093 \\
$r-\tilde{r}$ & $(1.832)$ & $(1.614)$ & $(1.132)$ \\
$R^{2}$ & & $0.0248^{*}$ & $0.0254^{*}$ \\
& -0.0308 & $(2.534)$ & $(2.592)$ \\
& $(1.602)$ & -0.0121 & -0.0117 \\
& 0.054 & $(1.466)$ & $(1.416)$ \\
& & 0.069 & 0.073
\end{tabular}

*******denote the significance at 1,5 and 10 percent levels.

Variables are deviated from expected trend, which uses polynomial trend method here.

$I=1$ denotes that there is no currency crisis or there is no successful attack; $I=0$ denotes that there is a currency crisis or there is a successful attack.

a successful attack. Regime 1 in both models is the normal period and regime 2 is the crisis period.

With respect to the single regime model, while the response of output to exchange rate changes is negative, it is statistically insignificant. Hence, using the single regime model leads us to reject the contractionary devaluation hypothesis. This is consistent with the negative trend and wide variations of sample in the previous figures.

With respect the first two-regime model, using the currency crisis periods to separate samples into the two regimes, the response coefficient turns out to be positive but is still insignificant in the normal regime. This is more consistent with the conventional wisdom that devaluation typically facilitates an output rebound. However, strongly negative responses are discernible in the crisis regime. While the coefficient (-0.0474) is close to that of a single-regime model, it is significant at the 1 percent level. Hence, the contractionary devaluation does not exist during the normal time. It only does so during the crisis period. This validates our emphasis on state-contingent devaluation, a point that appears to have been largely ignored 
by the New Structuralist School.

There is not much alteration in the results in the second two-regime model, where the crisis index is limited to the cases of a successful attack. The coefficient becomes slightly higher to -0.0521 and is also significant at the 1 percent level. Finally, the coefficient also increases slightly from 0.054 in the single-regime model to 0.069 in the first two-regime, and to 0.073 in the second two-regime model.

\section{B. Testing the Five Hypothesis}

Table 3 reports the estimation results assuming that response coefficient are functions of the five hypotheses alternatively. After plugging equation (2) into (1), the right hand of equation contains four interactive terms:

$$
\theta_{0}^{(1)}\left(e_{i t}-\tilde{e}_{i t}\right) I_{i t}+\theta_{0}^{(1)} z_{i}\left(e_{i t}-\tilde{e}_{i t}\right) I_{i t}+\theta_{0}^{(2)}\left(e_{i t}-\tilde{e}_{i t}\right)\left(1-I_{i t}\right)+\theta_{1}^{(2)} z_{i}\left(e_{i t}-\tilde{e}_{i t}\right)\left(1-I_{i t}\right)
$$

The coefficients of $\theta_{1}^{(1)}$ and $\theta_{1}^{(2)}$ represent the response of output to exchange rate variations with the presence of $z$ during the normal and the crisis periods, respectively. Since output does not drop during the normal period, our primary interest is the coefficient on the latter variable. In other words, for all the five hypotheses, the primary coefficient of interest is $\theta_{1}^{(2)} . I_{i t}$ is first proxied by the currency crisis index which encompasses the cases when a crisis is unsuccessful in the sense that it does not lead to a devaluation.

When $z$ is the GNP per capita, the coefficient is 0.0121 and is insignificantly different from zero. The positive coefficient means that the lower the GNP per capita, the lower the output for a given devaluation. While the sign is consistent with the New Structuralist hypothesis, it is statistically insignificant and is rejected.

We have four regional dummies, $D_{\text {Latin }}, D_{\text {Asia }}, D_{\text {Nordic }}$ and $D_{\text {MiddleE. }}$. The dummies equal unity if the countries are in that region, otherwise they are zero. As seen in Table 3 , in the absence of a currency crisis, the coefficients are significantly positive for Latin American, Asian and Middle Eastern countries, but insignificantly different from zero for Nordic countries. This suggests that, during the non-crisis period, while the overall effect is negative for currency devaluation, this negative effect is lessened in the first three regions, but remains unchanged for the Nordic countries. Results are sharply reversed during the currency crisis periods. Coefficients on the four regional dummies are overwhelmingly negative and highly significant at the 1 percent level, suggesting that the negative effect is 
Table 3. Testing the Five Hypotheses of Output Contraction During Currency Crisis

\begin{tabular}{|c|c|c|c|c|c|}
\hline & $\begin{array}{l}\text { GNP Per } \\
\text { Capita }\end{array}$ & $\begin{array}{l}\text { Regional } \\
\text { Effect }\end{array}$ & $\begin{array}{c}\text { Twin } \\
\text { Crises }\end{array}$ & $\begin{array}{l}\text { Short Term } \\
\text { Debt/Total }\end{array}$ & Corruption \\
\hline \multirow{2}{*}{ const. $\times I$} & -0.0037 & -0.0052 & -0.0032 & 0.0095 & -0.0036 \\
\hline & $(0.543)$ & $(0.7814)$ & $(0.460)$ & $(1.302)$ & $(0.541)$ \\
\hline \multirow{2}{*}{$(e-\tilde{e}) \times I$} & -0.0404 & $-0.3955^{*}$ & -0.0240 & -0.0095 & 0.0117 \\
\hline & $(0.324)$ & (7.8652) & $(1.263)$ & $(0.119)$ & $(0.118)$ \\
\hline \multirow{2}{*}{$(e-\tilde{e}) \times z \times I$} & 0.0024 & & -0.0003 & -0.0075 & -0.0063 \\
\hline & $(0.142)$ & & $(0.006)$ & $(0.221)$ & $(0.384)$ \\
\hline$(e-\tilde{e}) \times I \times D_{\text {Latin }}$ & & $\begin{array}{c}0.2916 \\
(2.0955)\end{array}$ & & & \\
\hline$(e-\tilde{e}) \times I \times D_{A s i a}$ & & $\begin{array}{c}4114 \\
(2.6976)\end{array}$ & & & \\
\hline$(e-\tilde{e}) \times I \times D_{\text {Nordic }}$ & & $\begin{array}{c}2950 \\
(1.1711)\end{array}$ & & & \\
\hline$(e-\tilde{e}) \times I \times D_{\text {Middle } E}$ & & $\begin{array}{l}2855^{* *} \\
(1.9877)\end{array}$ & & & \\
\hline \multirow{2}{*}{ const. $\times(1-I)$} & 0.0005 & -0.002 & 0.0003 & -0.0029 & 0.0004 \\
\hline & $(0.208)$ & $(0.0763)$ & $(0.154)$ & (1.108) & $(0.169)$ \\
\hline \multirow{2}{*}{$(e-\tilde{e}) \times(1-I)$} & $-0.1435 * * *$ & $-0.3166^{*}$ & $-0.0479 *$ & 0.0152 & $-0.1487^{*}$ \\
\hline & $(1.841)$ & $(2.2893)$ & $(4.785)$ & $(0.328)$ & $(5.733)$ \\
\hline \multirow{2}{*}{$(e-\tilde{e}) \times z \times(1-I)$} & 0.0121 & & -0.1205 & $-0.0271 * * *$ & $0.0202 *$ \\
\hline & $(1.240)$ & & $(0.095)$ & $(1.695)$ & $(4.182)$ \\
\hline$(e-\tilde{e}) \times(1-I) \times D_{\text {Latin }}$ & & $\begin{array}{c}-0.44394 * \\
(8.6783)\end{array}$ & & & \\
\hline$(e-\tilde{e}) \times(1-I) \times D_{A s i a}$ & & $\begin{array}{c}-0.6140^{*} \\
(10.2428)\end{array}$ & & & \\
\hline$(e-\tilde{e}) \times(1-I) \times D_{\text {Nordic }}$ & & $\begin{array}{l}-0.5849 * \\
(6.4071)\end{array}$ & & & \\
\hline$(e-\tilde{e}) \times(1-I) \times D_{\text {Middle } E}$ & & $\begin{array}{c}-0.4256^{* *} \\
(7.8448)\end{array}$ & & & \\
\hline \multirow{2}{*}{$g-\tilde{g}$} & 0.0120 & $0.0134 * * *$ & 0.0123 & 0.0074 & $0.0160 *$ \\
\hline & (1.444) & $(1.8326)$ & (1.495) & (1.036) & $(2.008)$ \\
\hline \multirow{2}{*}{$m-\tilde{m}$} & 0.0245 & $0.0233 *$ & $0.0252^{*}$ & $0.0364 *$ & $0.0240^{*}$ \\
\hline & $(2.460)$ & $(2.5381)$ & $(2.506)$ & $(4.010)$ & $(2.460)$ \\
\hline \multirow{2}{*}{$r-\tilde{r}$} & -0.0122 & $-0.0124 * * *$ & -0.0120 & -0.0029 & -0.0121 \\
\hline & $(1.400)$ & $(1.6573)$ & (1.399) & $(0.380)$ & $(1.488)$ \\
\hline$R^{2}$ & 0.072 & 0.265 & 0.093 & 0.179 & 0.120 \\
\hline
\end{tabular}

Absolute $t$ value in parenthesis; ***,*** denote the significance at 1,5 and 10 percent levels. All variables are deviated from expected trend, which uses polynomial trend method here. $I=1$ if there is no currency crisis; $I=0$ if there is a currency crisis.

exacerbated for the four regions if a currency crisis occurs. The regional effect does exist for the devaluation effect when there is the currency crisis.

When $z$ is the GNP per capita, the coefficient is -0.1205 . Though this coefficient 
is negative, suggesting that the banking crisis aggravates the declines of output, it is not significantly different from zero. Also, the response coefficient of $(e-\tilde{e}) \times I$ $(c c=1)$ changes little compared to that presented in Table 2 . Thus, the coincidence of a banking and a currency crisis appears to be of little help in accounting for a devaluation-induced output collapse.

When the ratio of short debt to total external debt ratio is used, the coefficient of interest is -0.0271 , and significant at only the 10 percent level. Hence, when there is a currency crisis, the higher the short term debt, the greater the drop in output ${ }^{13}$.

Lastly, the corruption hypothesis is also confirmed. The primary coefficient of interest is significantly positive at the 1 percent level. Because the corrupt indicator ranges from 1 to 10 , where a higher number indicates less corruption (better public governance), the positive response implies that the better the quality of public governance, the less likely that a currency crisis will be contractionary.

When $I_{i t}$ is replaced by successful attack, there are a few variations in the findings which warrant highlighting. In Table 4, GNP per capita becomes significant at the 10 percent level, which confirms the New Structuralist Hypothesis. The four regional dummies are again highly significant regardless of the sample period. In other words, the coefficients on the various regional dummies are negative even during the non-crisis period. The regional effect is significant at all times (i.e. both during crisis and non-crisis periods). The twin crisis variable is the incorrect sign but remains statistically insignificant. Results of the remaining two hypotheses are unaltered.

\section{Conclusion}

This paper has examined whether output declines when a fixed exchange rate regime is devalued. We find the output increases insignificantly during a "normal period" but drops during a "crisis period". In other words, the impact of devaluation is state-contingent. This in itself seems to be an important finding and has

\footnotetext{
${ }^{13} \mathrm{We}$ can only conjecture that this mildly significant result may be a result of two possibilities. First, our data has not distinguished between short debt denominated in local currency versus foreign currency. The high short term debt may not necessarily lead to significant output losses if it is denominated in local currency since the devaluation does not automatically worsen the net worth of the economy (i.e. so-called "balance sheet effect"). Second, high short term debt and the currency crisis dummy may be highly correlated since the response coefficient of $\theta_{0}^{(2)}$ becomes insignificant.

${ }^{14} \mathrm{~A}$ related issue is, if a currency peg is abandoned, what alternative form of nominal anchor will need to replace it (Bird and Rajan, 2002 and Eichengreen et al., 1999)?
} 
Table 4. Testing the Five Hypothesis of Output Contraction During Successful Attack

\begin{tabular}{|c|c|c|c|c|c|}
\hline & $\begin{array}{l}\text { GNP Per } \\
\text { Capita }\end{array}$ & $\begin{array}{l}\text { Regional } \\
\text { Effect }\end{array}$ & $\begin{array}{l}\text { Twin } \\
\text { Crises }\end{array}$ & $\begin{array}{l}\text { Short Term } \\
\text { Debt/Total }\end{array}$ & Corruption \\
\hline \multirow[t]{2}{*}{ const. $\times I$} & 0.0064 & -0.0017 & 0.0077 & 0.0075 & 0.0075 \\
\hline & $(0.838)$ & $(0.2307)$ & (1.061) & (1.031) & $(1.054)$ \\
\hline \multirow[t]{2}{*}{$(e-\tilde{e}) \times I$} & -0.0717 & $-0.0014^{*}$ & $-0.0303 * *$ & 0.0415 & $-0.2302 *$ \\
\hline & $(0.589)$ & $(0.6012)$ & $(2.166)$ & $(0.792)$ & $(3.788)$ \\
\hline \multirow[t]{2}{*}{$(e-\tilde{e}) \times z \times I$} & 0.0058 & & -0.1418 & -0.0311 & $0.0367 *$ \\
\hline & $(0.348)$ & & (1.361) & (1.623) & $(3.404)$ \\
\hline$(e-\tilde{e}) \times I \times D_{\text {Latin }}$ & & $\begin{array}{l}-0.2623^{*} \\
(4.6068)\end{array}$ & & & \\
\hline$(e-\tilde{e}) \times I \times D_{A s i a}$ & & $\begin{array}{l}-0.4297 * \\
(6.5268)\end{array}$ & & & \\
\hline$(e-\tilde{e}) \times I \times D_{\text {Nordic }}$ & & $\begin{array}{l}-0.3954 * \\
(4.1446)\end{array}$ & & & \\
\hline$(e-\tilde{e}) \times I \times D_{\text {Middle } E}$ & & $\begin{array}{l}-0.2446^{*} \\
(4.0783)\end{array}$ & & & \\
\hline \multirow[t]{2}{*}{ const. $\times(1-I)$} & -0.0011 & $0.5930^{*}$ & -0.001 & -0.0028 & -0.0014 \\
\hline & $(0.433)$ & $(6.0480)$ & $(0.415)$ & (1.070) & $(0.581)$ \\
\hline \multirow{2}{*}{$(e-\tilde{e}) \times(1-I)$} & $-0.2038 *$ & $-0.6272 *$ & $-0.0553 *$ & 0.0221 & $-0.1604 *$ \\
\hline & (2.239) & $(6.3570)$ & $(5.166)$ & $(0.440)$ & $(4.845)$ \\
\hline \multirow{2}{*}{$(e-\tilde{e}) \times z \times(1-I)$} & $0.0188 * * *$ & & 0.0648 & $-0.0306 * * *$ & $0.0194^{*}$ \\
\hline & $(1.685)$ & & (1.318) & $(1.720)$ & $(3.454)$ \\
\hline \multirow{2}{*}{$(e-\tilde{e}) \times(1-I) \times D_{\text {Latin }}$} & & $-0.6273 *$ & & & \\
\hline & & $(6.3570)$ & & & \\
\hline$(e-\tilde{e}) \times(1-I) \times D_{A s i a}$ & & $\begin{array}{l}-0.5859 * \\
(52179)\end{array}$ & & & \\
\hline \multirow{2}{*}{$(e-\tilde{e}) \times(1-I) \times D_{\text {Nordic }}$} & & $-0.7178^{*}$ & & & \\
\hline & & (2.8799) & & & \\
\hline$(e-\tilde{e}) \times(1-I) \times D_{\text {Middle } E}$. & & $\begin{array}{l}-0.6209^{*} \\
(6.0190)\end{array}$ & & & \\
\hline \multirow[t]{2}{*}{$g-\tilde{g}$} & 0.0085 & $0.0134 * * *$ & 0.0091 & 0.0074 & 0.0085 \\
\hline & (1.029) & (1.7319) & (1.105) & (1.018) & (1.063) \\
\hline \multirow[t]{2}{*}{$m-\tilde{m}$} & $0.0248 *$ & $0.0212^{*}$ & $0.0282^{*}$ & $0.036^{*}$ & $0.0225^{*}$ \\
\hline & $(2.504)$ & $(2.2528)$ & $(2.805)$ & (3.909) & $(2.347)$ \\
\hline \multirow[t]{2}{*}{$r-\tilde{r}$} & -0.0125 & $-0.0144 * * *$ & -0.0136 & -0.0034 & -0.0118 \\
\hline & $(1.463)$ & (1.8848) & (1.613) & $(0.446)$ & $(1.466)$ \\
\hline$R^{2}$ & 0.078 & 0.231 & 0.093 & 0.178 & 0.120 \\
\hline
\end{tabular}

Absolute $t$ value in parenthesis; *,***** denote the significance at 1,5 and 10 percent levels. All variables are deviated from expected trend, which uses polynomial trend method here. $I=1$ if there is no successful attack; $I=0$ if there is a successful crisis.

implications for an exit strategy between a pegged regime to a more flexible one. In particular, our analysis suggests that such a transition is best made during a 
period of relative calm (Eichengreen et al., 1999) ${ }^{14}$.

Having linked a currency crisis and exchange rate devaluation with economic collapse, we proceeded to establish the circumstances under which a crisis-induced devaluation may exert a recessionary influence. Drawing on recent literature on currency crisis, we outlined five hypotheses to explain the reasons for a crisisinduced output contraction. The five hypotheses are: the "Income effect", based on the New Structuralist hypothesis; "Regional effect" to capture regional contagion effects; "twin crisis, to denote the coincidence of a banking crisis and currency crisis; "Excessive Debt effect" and "Corruption effect" both of which capture aspects of composition of capital flows (i.e. short term capital flows are more easily reversible and potentially damaging to the real economy). The Corruption effect serves a dual purpose, also acting as a proxy for particular attributes of insolvency.

While all estimated coefficients have the anticipated signs, we reject outright the twin crisis hypothesis on the basis of the data and proxies available. This may be partly due to difficulties in accurately dating banking crises, let alone twin crises. Our results are broadly supportive of the other three hypotheses which emphasize the importance of contagion and composition of capital flows. There is also weak evidence in support of the New Structuralist thesis. Taken as a whole, these findings may provide reason to pause before recommending devaluation to every country in the midst of a crisis, and to think carefully about what policies should accompany such an expenditure switching policy if implemented.

\section{Acknowledgments}

Earlier versions of this paper were presented at the IGIDR in Mumbai and the Federal Reserve Bank of SanFrancisco. This paper was revised while the author was a Visiting Freeman Foundation Scholar at the Department of Economics, Claremont McKenna College (CMC). The author is grateful for the generous support provided by the Freeman Foundation as well as for the first-rate research facilities made available to him at the Lowe Institute of Political Economy. The usual disclaimer applies. 


\section{References}

Agenor, P. (1991). "Output, Devaluation, and the Real Exchange Rate in Developing Countries", Weltwirtschaftliches Archiv, 127, pp.18-41.

Agenor, P., J. Aizenman and A. Hoffmaister (2000). "The Credit Crunch in East Asia: What Can Bank Excess Liquid Assets Tell Us?”, Working Paper No.7951, NBER.

Aghion, P., P. Bacchetta and A. Banerjee (2000). "A Simple Model of Monetary Policy and Currency Crises", European Economic Review, 44, pp.728-738.

Bird, G. and R. Rajan (2002). "Optimal Currency Baskets and the Third Currency Phenomenon: Exchange Rate Policy in Southeast Asia", Journal of International Development, 14, pp.1053-73.

Bird, G and R. Rajan (2004). "Does Devaluation Lead to Economic Recovery or Economic Contraction?: Examining the Analytical Issues with Reference to Thailand", Journal of International Development, 16. pp.141-56

Calvo, G. (1994). "Comments on Dornbusch-Werner", Brookings Papers on Economic Activity, 2, pp.299-303.

Calvo, G. (1996). "Capital Flows and Macroeconomic Management: Tequila Lessons", International Journal of Finance and Economics, 1, pp.207-23.

Calvo, G. and C. Reinhart (2000). "When Capital Inflows Come to a Sudden Stop: Consequences and Policy Options", in P. Kenen, M. Mussa, and A. Swoboda (eds.), Key Issues in Reform of the International Monetary and Financial System, Washington, DC: International Monetary Fund.

Calvo, S. and C. Reinhart (1996). "Is there Evidence of Contagion Effect", in G. Calvo, M. Goldstein and E. Hochreiter (eds.), Private Capital Flows to Emerging Economies After the Mexican Crisis, Washington, DC: Institute for International Economics.

Chang, R. and A. Velasco (1999). "Liquidity Crises in Emerging Markets: Theory and Policy", in B. Bernanke and J. Rotemberg (eds.), NBER Macroeconomics Annual 1999, Cambridge, MA: MIT Press.

Cooper, R. (1971). "Currency Devaluation in Developing Countries", Princeton Essays in International Finance No.86, International Economic Section, Princeton University.

Corsetti, G., P. Pesenti and N. Roubini (2000). "Competitive Devaluations: Toward a Welfare-Based Approach", Journal of International Economics, 51, pp.217-41.

Dadush, U., D, Dasgaupta and D. Ratha (2000). "The Role of Short-term Debt in Recent Crises", Finance and Development, 37, pp.54-7.

De Gregario, J. and R. Valdes (2001). "Crisis Transmission: Evidence from the Debt, Tequila, and Asian Flu Crises", in S. Claessens and K. Forbes (eds.), International Financial Contagion, Boston: Kluwer Academic Publishers.

Diamond, P. and P. Dybvig (1983). "Bank Runs, Deposit Insurance, and Liquidity", Journal of Political Economy, 91, pp.401-19.

Diaz-Alejandro, C. (1963). "A Note on the Impact of Devaluation and the Redestributive Effects", Journal of Political Economy, 71, pp.577-80. 
Dooley, M. and C. Walsh (2000). "Capital Controls and Crises: Theory and Experience", mimeo (undated). Paper presented at AEA Meetings, June.

Dornbusch, R. (1988). Open Economy Macroeconomics, $2^{\text {nd }}$ edition, New York: Basic Books.

Edwards, S. (1986). "Are Devaluations Contractionary?", Review of Economics and Statistics, 68, pp.501-8.

Edwards, S. (1989). Real Exchange Rates, Devaluation, and Adjustment: Exchange Rate Policy in Developing Countries, Cambridge, MA: MIT.

Eichengreen, B., P. Masson, M. Savastano and S. Sharma (1999). "Transition Strategies and Nominal Anchors on the Road to Greater Exchange-Rate Flexibility", Essays in International Finance, International Economics Section, Princeton University.

Eichengreen, B. and A. Rose (2001). "Does it Pay to Defend Against a Speculative Attack?", mimeo (April).

Fernández-Arias, E. and R. Hausmann, R. (2000). "Foreign Direct Investment: Good Cholesterol?", Working Paper No.417, Inter-American Development Bank.

Fernández-Arias, E. and R. Hausmann (2001). "Is FDI a Safer Form of Financing?" Emerging Markets Review, 2, pp.34-49.

Frankel, J. and S. Schmukler (1996). "Crisis, Contagion, and Country Funds: Effects on East Asia and Latin America”, Working Paper No.96-04, Center for Pacific Basin Monetary and Economics Studies, Federal Reserve of San Francisco.

Furman, J. and J. Stiglitz (1998). "Economic Crises: Evidence and Insights from East Asia", Brookings Papers on Economic Activity, 2, pp.1-114.

Gerlach, S. and F. Smets (1995). "Contagious Speculative Attacks", European Journal of Political Economy, 11, pp.5-63.

Glick, R. and M. Hutchison (1999). "Banking and Currency Crises: How Common Are Twins?", Working Paper No.PB99-07, Center for Pacific Basin Monetary and Economic Studies, Federal Reserve Bank of San Francisco.

Glick, R. and A. Rose (1999). "Contagion and Trade: Why are Currency Crises Regional?", Journal of International Money and Finance, 18, pp.603-17.

Goldfajn, I. and T. Baig (1998). "Monetary Policy in the Aftermath of Currency Crises: The Case of Asia", Working Paper No.98/170, IMF.

Goldfajn, I. and R. Valdes (1997). "Capital Flows and the Twin Crises: The Role of Liquidity”, Working Paper No.97/87, IMF.

Goldstein, M., G. Kaminsky and C. Reinhart (2000). Assessing Financial Vulnerability: An Early Warning System for Emerging Markets, Washington, DC: Institute of International Economics.

Hausmann, R. (1999). "Currencies: Should there be Five or One Hundred and Five", Foreign Policy, 116, pp.65-79.

Hutchison, M. (2001). "A Curse Worse Than the Disease?: Currency Crises and the Output Costs of IMF-supported Stabilization Programs", Working Paper No.8305, NBER.

Huh, C. and K. Kasa (1997). “A Dynamic Model of Export Competition, Policy Coordina- 
tion, and Simultaneous Currency Collapse”, Working Paper No.97-08, Center for Pacific Basin Monetary and Economics Studies, Federal Reserve of San Francisco. Kamin, S. (1988). "Devaluation, External Balance, and Macroeconomic Performance: A Look at the Numbers", Princeton Studies in International Finance No.62, International Economics Section, Princeton University.

Kamin, S. and M. Klau (1998). "Some Multi-Country Evidence on the Effects of Real Exchange Rates on Output", International Finance Discussion Papers No.611, Board of the Governors of the Federal Reserve.

Kamin, S. and J. Rogers (2000). "Output and the Real Exchange Rate in Developing Countries: An Application to Mexico", Journal of Development Economics, 61, pp. 85-109.

Kaminsky, G. and C. Reinhart (1999). "The Twin Crises: The Causes of Banking and Balance-of-Payments Problems”, American Economic Review, 89, pp.473-500.

Kaminsky, G. and C. Reinhart (2000). "Bank Lending and Contagion: Evidence from the Asian Crisis", in T. Ito and A. Krueger (eds.), Regional and Global Capital Flows: Macroeconomic Causes and Consequences, Chicago: University of Chicago Press.

Knight, J. (1976). "Devaluation and Income Distribution in Less Developed Economies", Oxford Economic Papers, July.

Kraay, A. (2000). "Do High Interest Rates Defend Currencies during Speculative Attacks?", Policy Research Working Paper No.2267, World Bank.

Krueger, M., P. Osakwe and J. Page (2000). "Fundamentals, Contagion and Currency Crises: An Empirical Analysis", Development Policy Review, 18, pp.257-74.

Krugman, P. (1979). "A Model of Balance of Payments Crises", Journal of Money Credit and Banking, 11, pp.311-328.

Krugman, P. (1998). "Latin America's Swan Song”, mimeo (undated).

Krugman, P. (1999a). "What Happened to Asia?", in R. Sato, R. Ramachandran and K. Mino (eds.), Global Competition and Integration, Boston: Kluwer Academic Publishers, pp.315-328.28.

Krugman, P. (1999b). "Balance Sheets, The Transfer Problem, and Financial Crisis", in P. Isard, A Razin and A. Rose (eds.), International Finance and Financial Crises, Boston: Kluwer Academic.

Lane, T., A. Ghosh, J. Hamann, S. Phillips, M. Schultze-Ghattas and T. Tsikata (1999). "IMFSupported Programs in Indonesia, Korea, and Thailand: A Preliminary Assessment", Occasional Paper 178, IMF.

La Porta, R., F. Lopez-de-Silanes, A. Shleifer and R. W. Vishny (1998). "Law and Finance", Journal of Political Economy, 106, pp.1113-55.

Lane, T., A. Ghosh, J. Hamann, S. Phillips, M. Schultze-Ghattas and T. Tsikata (1999). "IMF-Supported Programs in Indonesia, Korea, and Thailand: A Preliminary Assessment”, Occasional Paper 178, IMF.

Lindgren, C. T. Balino, C. Enoch, A. Gulde, M. Quintyn and L. Teo (1999). Financial Sector Crisis and Restructuring: Lessons from Asia, Washington, DC: IMF.

Lizondo, S. and P. Montiel (1989). "Contractionary Devaluation in Developing Countries", 
IMF Staff Papers, 36, pp.182-227.

Morley, S. (1992). "On the Effects of Devaluation During Stabilization Programs in LDCs", Review of Economics and Statistics, 64, pp.21-7.

Moreno, R. (1999). "Depreciation and Recessions in East Asia", Economic Review, 3, Federal Reserve Bank of San Francisco, pp.27-41.

Rajan, R. (2001). "(Ir)relevance of Currency Crises Theory to the Devaluation and Collapse of the Thai Baht", Princeton Study in International Economics No.88, International Economics Section, Princeton University.

Rajan, R. (2002). "Exchange Rate Policy Options for Southeast Asia Revisited: Is There a Case for Currency Baskets?", The World Economy, 25, pp.137-63.

Rajan, R. and R. Siregar (2002). "Private Capital Flows in East Asia: Boom, Bust and Beyond", in G. de Brouwer (ed.), Financial Markets and Policies in East Asia, London: Routledge.

Rodrik, D. (2000). "Exchange Rate Regimes and Institutional Arrangements in the Shadow of Capital Flows", mimeo (September).

Rodrik, D. and A. Velasco (1999). "Short-Term Capital Flows", Working Paper No.7364, NBER.

Santaella, J. and A. Vela (1996). "The 1987 Mexico Disinflation Program: An Exchangerate Based Stabilization", Working Paper No.96/49, IMF.

Shen, C. H. (1999). "Are They Really Twin: Evidence from Panel Cointegration", paper presented at $9^{\text {th }}$ Security and Capital Market, Kaushiong, Taiwan (December).

Stone, M. (2000). "Large-Scale Post-Crisis Corporate Sector Restructuring, Working Paper PDP/007, IMF.

Taylor, L. (1981). "IS/LM in the Tropics: Diagrammatics of the New Structuralist Macro Critique", in W. Cline and S. Weintraub (eds.), Economic Stablization in Developing Countries, Washington, D.C.: The Brookings Institution.

van Wijnbergen, S. (1986). "Exchange Rate Management and Stabilization Policies in Developing Countries", Journal of Development Economics, 23, pp.227-47.

Velasco, A. (1987). "Financial Crises and Balance of Payments Crises: A Simple Model of the Southern Cone Experience", Journal of Development Economics, 27, pp.263-283.

Wei, S.J. (2001). "Corruption and Globalization", Policy Brief No.79, Brookings Institution.

Wei, S.J. and Y. Wu (2001). "Negative Alchemy? Corruption, Composition of Capital Flows, and Currency Crises", Working Paper No.8187, NBER.

World Bank (2000). Global Development Finance 2000, New York: Oxford University Press. 